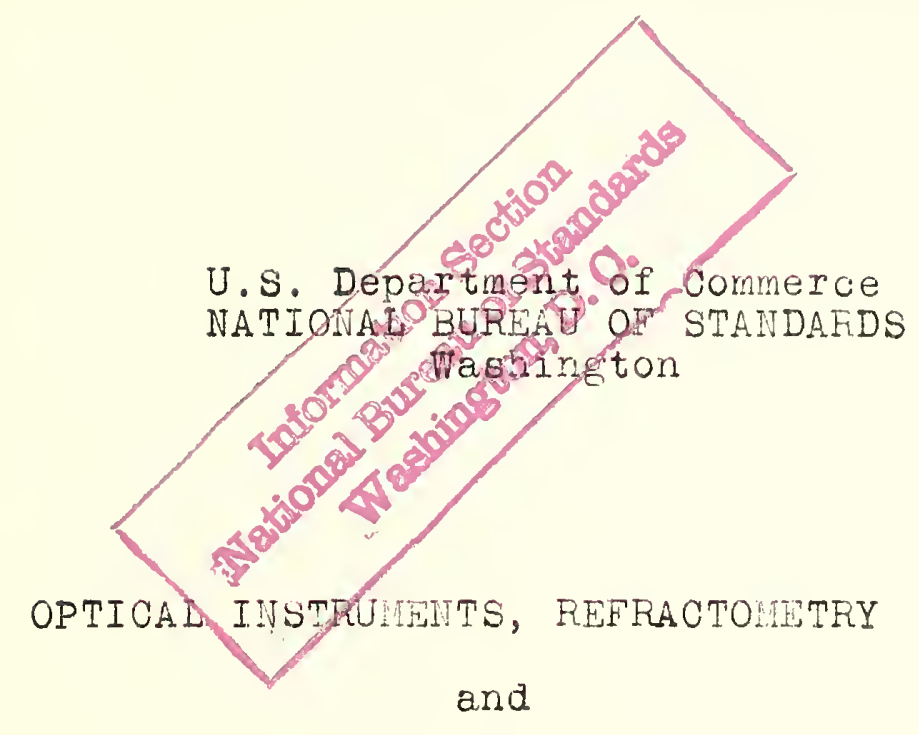

OPTICAL PROPERTIES OF' GLASS:

Publications by the Staff of the National Bureau of Standards. 


$$
\text { , . }
$$


FEN:AIB

U. S. DEPARTMENT OF CONHERCE NATIONAL BUTREAU OF STANDARDS WASHINGTON
Letter

Circular

LC-673

(supersedes

LC-571)

Novermber 26, 1941

OPTICAL INSTRUMENTS, REFRACTOMETRY

and

OPTICAL PROPERTIES OF GLASS:

Publications by the Staff of the National Bureau of Standards.

Contents

Page

I. General information .................. 2

II. Photogrammetry ..................... 5

III. Photograbinic objectives ................ 6

IV. Design and construction of optical instruments ... 7

T. Testing and use of optical instruments ........ 9

VI. Miscellaneous napers on optical instruments ...... I0

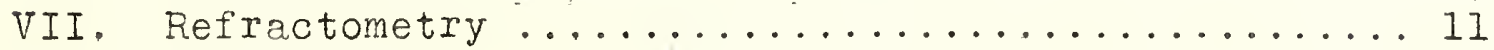

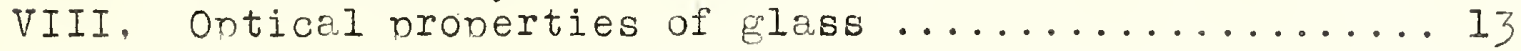




\section{GENERAI IUHORIATION}

Sorne of the nublications in this list have appeared in the regular series of publications of the Bureau and others in various scientific and technical journals. Unless otherwise specifically stated, papers are not obtainable from the liational Bureau of standards.

Where the price is stated, the publication can be nurchased from the Superintendent of Documents, Government Printing office, Washington, D.C. The prices quoted are for delivery to addresses in the United States and its territories and possessions and in certain foreign countries wiich extend the franking orivilege. In the case of all other countries, one-third of the cost of the publication should be added to cover postage. Remittances should be made either by coupons (obtainable from the superintendent of Documents in sets of 20 tor $\$ 1.00$ and good until used), or by check or money order payable to the "Superintendent of Documents, Government Printing office" and sent to him with order..

Publications rnarked "OP" are out of print, but, in general, may be consulted at technical libraries.

For papers in other scientific or technical journals, the name of the journal or of the orgarlization publishing the article is given in abbreviated form, vith the volume number (underscored. page, and year of publication, in the order named. The Bureau can not sunply copies of these journals, or renrints from them, and it is unable to furnish information as to their availability or nrice. They, too, can usually be consulted at technical libraries.

Series letters with serial numbers are used to designate Bureau publications:

$S=$ "Scientific Paner". SI to 5329 are "Reprints" from the "Bulletin of the Bureau of Standards". S330 to $\$ 572$ were nublished as "Scientific Papers of the Bureau of Standards". Tnis series was superseded by the "Bureau of Standards Journal of Research" in 1928.

$T=$ "Technologic Paper". TI to T370. This series vas superseded by the "Bureau of Standards Journal of Research" in 1928 .

$\mathrm{RP}=$ "Research Paper". These are reprints of articles anpearing in the "Bureau of Standards Journal of Research" and 
the "Journal of Research of the National Bureau of Standards", the latter being the title of this periodical since July 1934 (volume 13, number 1).

$c=$ "Circular".

$M=$ "Miscellaneous Publications":

LC = "Letter Circular", a mimeographed pamphlet obtainable from the National Bureau of Standards without charge.

Circular 024 and supplements giving the complete list of the Bureau's publications (1901-1936), are sold by the superintendent of Documents for 55 cents. Announcement of new publications is made each month in the Technical News Bulletin which is obtainable from the same source by subscription at 50 cents ner year. 
Inquiries regarding the nurchase of back numbers of magazines containing amy of the articles listed, in non-governmental publications slould be addressed to the publisliers. For this purpose their addresses are given in the list which follows:

American Machinist,

McGraw IIII Publishing: Co.,

330 m. $42 n d$ st. ,

New York, N. Y.

Annual Report of Comnressed Gas lipnufacturers Ass'n., Inc., Compressed Gas Màufacturers Ass'n., Inc.,

120 West 4 2na st.

New York, N.Y.

Army Ordnance,

The Army Ordnance Association,

Mils Builaing,

I7th St. and Pennsylvaria Ave.,

Waskington, D.C.

Astronomical Society of the Pacific,

318 Merchants Exchange BIdg.,

San Francisco, Calif.

Journal of American ceramic society,

$2525 \mathrm{H}$. High st. ,

Columbus, Orio.

Journal of the optical society of America and Review

of Scientific Instruments,

American Institute of Physics,

175 riftis Avenue,

Iiev York, i. Y.

Nature,

St. Martin's street,

London, w. C. 2, Ergland.

The Military Envineer,

Milis Builaing,

17 th st. and Penrsylvania Ave.,

Hashington, D.C.

National Geographic Magazine,

l6th and M Sts., N. W.,

Washington, D.C.

Photogrammetric Engineering,

724 Ninth St., N.W.,

Mashington, D.C. 


\section{PHOTOGRAIMETRY}

Title

Series Price

Optical requirements of airplane mapning. I.C. Gardner. BS J. Research \& 445 (1932) 11 pp.

5 illus. - . . . . - . - . . - RP427 50

Relation of camera error to photogrametric

mapping. I.C. Garaner. J. Research NBS

22, 209 (1939) 30 pp. 6 illus. . . . . RP1177 100

Locating the principal point of precision air-

plane mapning caneras. $F \cdot \mathbb{E}_{0}$ Wasner. J.

Research NBS $\underline{27}, 405$ (1941) 7 po. 3 ilius. - RP1428 10c

A magnifying stereoscope and camera: two instru-

ments for airplane manbing. I.C. Gardner.

J. Ont. Soc. Am. and Rev. Sci. Insts. II,

No. 2, 195, (1925).

The interpretation and uses of lens tests and camera calibrations. I.C. Gardner. Photogrammetric Engineering 3, No. 1, 12 (1937).

Specifications for a precision mpping cànera.

I.C. Gardner. Photogrammetric Engineering

4. Io. 3, 173 (1939). 
III. PHOTOGKAPHIC OBJECTIVES

\section{Title}

Axial aberrations of lenses. E.D. Tillyer.

and F.I. Schultz. BS Sci. Pap. 14,

341 (1918-19) 29 pn. 27 illus. _- - . - s 311

$\mathrm{OP}$

Aberrations of long focus anastigmatic photo-

granhic Ienses. A.H. Bennett. BS Sci.

Pap. 19, $587(1923-24) 54 \mathrm{mn} 52$ illus. - - 5494 OP

Precision canera for testing lenses. I.C.

Gardner and F.A. Case. J. Research

NBS Is, 449 (1937) 12 pp. 8 illus. - . - - RP984

Resolving power and distontion of typical air-

plane-camera lenses: F.E. Washer. J.

Research NBS 22, 729 (1939) I8 pp.

4 illus. ․ - _ . . . . . . . . RP1216

Cherts for testing lens resolution. (1940).

48 charts. _ . . . . . . . . . . M166

A tezt f lens resolution Ior the photogranker.

I.C. Gardner. (1941) 15 DD. 7 illus. - - c428

The distortion of some tynical photogranhic objectives. A.H. Bennett. J. Ont. Soc. Am. and Rev. Sci. Insts. 14, No. 3, 235 (1927).

The comensation of distortion in objectives for airplane nhotogranhy. I.C.Gardner and A.H. Bennett. J. Ont. Soc. Am. and Rev. Sci. Insts. 14, Mo. 3, 245 (1927). 
IT. DESIGIT AND COISTRUCTIOH OH OPTICAL INSTRUITENTS

Series Price

Spherical aberration of thin lenses. T.T. Srith.

BS Sci. Pan. 18,559(1922-23) 26 po. 15

illus. . - - - - - - - - - . . 4461 OP

Application of the algebraic aberration equetions.

to optical design. I.C. Gardner. BS Sci.

Pan. 르, $73(1927-28) 131$ on. 55 illus. - - 5550 OP

Making of uirrors by deposition of metal on glass.

(1931) 19 nn. 2 ilius. . . . . . . . . 0389100

Onticel coincidence gage. I.C. Gardner and F.A.

Case. BS J. Research 6,229 (1931) 9 po.

5 illus. . . . . . - . . . . . . RP272 100

Reciprocal snherical aberration of an ontical

system including higher orders. Farold F.

Bennett. Bg I. Research 9, 187 (1932) 39 po.

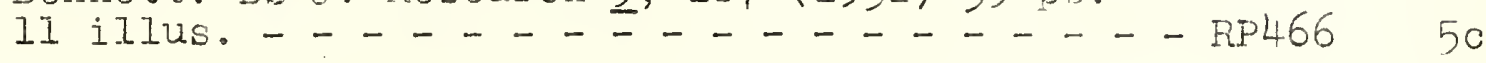

Attachment for turning annroximately spherical

surfaces of small curvature on a lathe.

I.C. Gardner. BS J. Research 9, 227 (Iyz2)

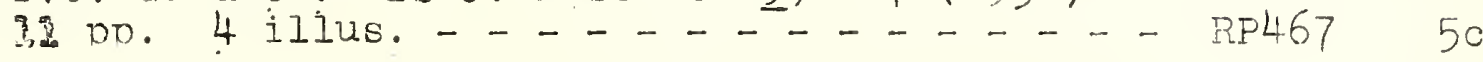

Compound lens systems. T. Tomsend Smith. J.

opt. Soc. Am. 1, INo. 4, 113 (1917).

The cemented telescope objective of barium crown

and flint. I.G. Gardner. J. Ont. Soc. Am.

4. 10. 5,274 (1920).

The coincidence type of self-contained range finder.

I.C. Gardner. T. Ont. Soc. Am. 5, No. 5, 420

(1921).

Constructional data for a cenented telescope ob-

jective of barium crown and flint. I.C.

Garaner. J. Ont. Soc. Am. and Rev. Sci.

Insts. 6, ito. 3, 379 (1922).

A field telemeter tor annroximate surveying. I.C.

Gardner. J. Opt. Soc. Am, and Rev. Sci. Insts.

6, No. 5, 489 (1922). 


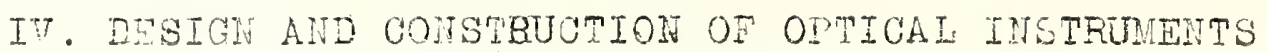
(conisinued)

Title

Image curvature as a function of dianhragm nosition. I.C. Gardner and J.J. Arnaud. J. Ont. Soc. Amo and Rev. Sci. Insts. 9, 10. 5,675 (1924)。

A canera for nhotouraphing the interior of a rifle borreI. I.C. Garaner and F.A. Case. J. Ont. Soc. Am. and Rev. jci. Insts. 12, $159(1926)$.

An ontical system for reading the ankular deflection of 3 . mirror. I.C. Gardner. J. Opt. Soc. An. and Rev. Sci. Insts. 12, 529 (1926).

Optical methods for testing cumpressed gas containers. I.C. Gardiner. Fourteenth Ann. Ren., Compressed Gas llanufacturers' Ass'n. Inc. $24(\operatorname{Jan} .1927)$.

Spherical surfoces of slight curvetures. I.C.

Gardner. An. Macrinist 76, 994 (sent. 1972). 


\section{TESTING AID USE OF OPTICAL INSTRUMTNTS}

Title

Series Price

Testing and properties of optical instrunents.

(1918). 41 pp. 1 ilius. _ . . . . . . . 027 OP

Wew ethod for determining the focal length of

a converping lens. I.G. Priest. 35 Sci.

Pan. 5, 483 (1908-09) 15 pr. I illus. - - - \$110 OP

Resolving nower of objectives. P.G. Nutting.

BS Sci. Pap. 6, 121 (1909-10) 5 pp. 1 ilius.- - S122 OP

Micrometer microscones. A.H. Gray. BS Sci. Pan.

10, 375 (1914) 16 on. 3 illus. … - . 5215 OP

Interference method for the aetermination of

axial and obliaue aberrations. A.F. Benrett.

BS J. Research 2, 685 (1929) 18 pp. 11 illus. - RP52 OP

Lateral chromatic aberration of apochromatic

microscope systems. I.C. Gardner and F.A.

Case. BS J. Research 6, 937 (1931) 10 np.

3 ilius. . . . . . . . . . . . . . . 316 50

Anparatis for the testing of binocular teles-

copes. T. Townsend Smiti. T. Opt. Soc.

Am. 2, 3 , Nos. 3-6, 76-90 (1919).

A modified Hartmann test based on interference.

I.C. Garaner and A.F. Bennett. J. Opt. Soc.

Arn. and Rev. Sici. Insts. 11, No. 4, 441, (1925).

Photographing the bore of a rifle. I.C. Gerdiner. The Military Engineer 18, 480 (1926).

A modified artmann test based on interference.

I.C. Gardner and A.F. Bernett. (translated from paper in J, Opt. Soc. Am. and Rev. Sci. Insts. 1925) Zeitschrift f粆 Instrunentenkunde 4, No. 47, 197 (1927).

An optical coincidence gage. I.G. Gardner. Am.

Machinist 74 , No. 4, 155 (1931). 
VI. MISCELIAIEOUS PAPERS ON OPTICAL INSTRUMEMTS

\section{Title}

Series Price

wpecifications for marire sextants.

(1921). $8 \mathrm{pp} . \ldots \ldots+\ldots$ C110 OP

Representation of aberration diffraction effects

by means of rotating sectors. A.F. Bernett.

BS J. Research 3, 391 (1929) 8 pn. 9 illus.- FPlO2 OP

"Camera Finish" at the race track. I.C. Garkner.

J. Research IJBS 18, 467 (1937) 8 pp. 3 illus. - RP986 50

Radiometry: Pliblications by the staff of the

National Esureau of Standirds. (1941).- - - Lo635 Free

The standardization of ontical fire control

instruments. I.c. Gardner. Army ordnance

5, 512 (Sent.oct. 1924).

Making a stancara of planeness. C.A. Skinner.

General Rlectric Rev. 29, I0. 8, 528

(August 1926).

Observing an eclipse in Asiatic Bussia. I.C.

Grudrer. National Geogranhic Magazine

II, 179 (1937).

Corona vhctography during the eclipses of 1936

and 1937. I. C. Gardner. National Geograpnic

Society, gontributed Teehnical papers, Solar

Eclinse Series, No. I, 39 (1939). 
VII. REFRACTOMETRY

Title

Series Price

Prism refractometry and certain. gonionetrical

requirements for precision. I. T. Tilton.

Bs J. Research ㄴ, 909 (1929) $22 \mathrm{pp}$.

2 ilius. _ . _ . . . . . . . . RP64 100

Prism size and orientation in mininun devia-

tion refractonetry. I. T. Tilton. BS J.

Research. 6, 59 (1931) lo po. 6 illus. - - RP262 100

Permissible curvature of prism surfaces and

inaccuracy of collimation in precise

minirnum-deviation refractometry. L. V.

Tilton. BS J. Research 11, 25 (1933)

33 po. 9 illus. _ . . . - . $\ldots$ RP575 50

Variations in refractive index of $\mathrm{CO}_{2}$-free

air and a statistical correlation with

solar activity. I.W. Tilton. J. Research

INBS 13, 111 (1934) 14 pp. 2 illus. - - - RP695 50

Refractive index and dispersion of normal and

heavy vater. I. T. Tilton and J.I. Taylor.

J. Research ITBS 13, $207(1934) 3$ pp. ... RP703 50

Standard ronditions for precise vrism refracto-

retry; L.W. Tilton. J. Research TBS 14, 393

(1935) 26 pp. I ilius. . . . . . - RP776 50

A thin cell for use in determining the reiractive indices of crystal grains. C.P. Saylor.

BS J. Research 15, 97 (1935) 2 pp. I illus.- - RP814 50

Thernal control in minimum-deviation refracto-. metry and temperature coeficients for a medium flint glass. L.W. Tilton. J. Research IBS 17, 389 (1936) 12 pp. 5 111us. - RP919 5c

Accurate representation of refractive index of distilled water as a function of wavelength. I.H. Tilton. J. Research NBS I7, 639 (1936) 12 pp. 2 illus. … . . - . RP934 50

Accurate renresentation of the refractivity and density of distilled water as a function of temperature. L.W. Tilton and J.K.

Taylor. J. Research JBS 18, 205 (1937)

10 pn. 2 illus. … $\ldots \ldots$. $\ldots$. . . .

$5 c$ 
VII. REFRATOMETRY (continued)

Title

Series Price

Refractive inder and dispersion of distilled

water for visible raciation, at temera-

tures 0 to $60^{\circ} \mathrm{C}$. L.W. Tilton and J.K.

Taylor. J. Research NBS 20, 419 (1938)

59 pn. 19 illus. . . . - . . . . . RP1085 150

Sunspot number and the refractivity of ary

air. I. Tilton. Tature (London) 132,

$855(1933)$. 
VIII. OPTICAL PROPERTIES OF・GLASS

Title

$\underline{\text { Series }} \underline{\text { Price }}$

Glasses for protecting the eyes from injuri-

ous radiations. W.W. Coblentz and W.B.

Emerson. Tech. Pan. BS To. 93, lst Ed.,

1917; 2nd Fd. 1918; 3rd Ed. 1919. - _ . . - T93 OP

Ootical conditions accomnanying the striae

which apnear as imperfections in optical

glass. A.A. Michelson. BS Sci. Pap.

15, 41 (1919-20) 5 pn. 4 illus. _ . . - . 5333 OP

Characteristics of striae in optical glass.

T.T. Smith, A.E. Bennett, and G.E. Iferritt.

BS Sci. Pap. 16, 75 (1920) 18 pp. 19 illus. - - S373 OP

Measurements of tne index of refraction of glass

at high temperatures. C.G. Peters. BS Sci.

Pap. 20, 635 (1924-26) 25 pp. 14 ilius. . . . 5521 10c

Cause and renoval of certain heterogeneities in

glass. I. T. Tilton, A.I. Finn, and A.

Tool. BS Sci. Pep. 22, 719 (1927-28) $18 \mathrm{pp}$.

7 illus. _ . . _ . . . . . . . 5572 OP

Transinissive properties of eve nrotective glasses

and other substances. W.H. Coblentz and R.

Stair. Tech. Pad. BS 22, 555 (1928) $24 \mathrm{pm}$.

15 ilius. … . . . . . . . . . . 369 OP

Ontical heterogeneity of a fused ouartz disk.

L."T. Tilton and A.Q. Tool, BS J. Research

3, 619 (1929) 10 pp. 2 ilius. $\ldots \ldots$ RPII? 50

Index of refraction of some soda-lime-silica

glasses as a function of the comósition.

C.A. Faick and A.N. Finn. BS J. Research

6, 993 (1931) 10 pn. 3 illus. $\ldots \ldots$ RP320 OP

Restoration of solarized ultra-violet trans-

mitting glasses by heat treatment. A.2.

Tool and R. Stair. BS J. Research I, 357

(1931) 18 pp. 5 ilius. … . . … RP345 10c

Index of refraction, density, and tiermal ex-

pansion of sone soda-alumina-silica glasses

as functions of the composition. C.A.

Faick, J.C. Young, D. Hubbard, and A.T. Finn.

J. Research NBS 14, 133 (1935) 5 on. 4 illus. - RP762 50 
VIII. OPTICAL PEOPIRTIES OF GLASS (continued)

\section{Title}

Publications on glass technology and a Iist of standard samoles of interest to the glass industry (1935). - - - - - - . - JC350 Free

Spectral-transmissive properties and use of

colored eye-protective glass. W. Coblentz

and R. Stair. (1938): - - . - . - . - 0421

Eflect of comosition and other factors on the specific refraction and dispersion of glasseś. J.C. Young and A.IN. Finn. BS J. Research 25,

759 (1940) 24 pp. 5 ilius. . - . - - - - RPI353

Optical glass. Heber D. Curtis. Pub., Astronomical Soc. Pacific 31 , No. 180, 77 (1919).

Some Iight transmissive characteristics of eye glasses. W. Coblentz. The central J. of Homeopathy 5, 597 (1924).

Regrading the heat treatrient of glass and its refractivity ard density. A. . Tool, L.W. Tilton, and E.R. HiIl. J. Opt. Soc. Am. and Rev. Sci. Insts. 12, No. 4, 490 (1926).

Some effects of calefully annealing optical glass. I.W. Tilton. J. Wash. Acad. Soi. 20, iNo. I, 12 (1930).

The transmissive properties of tinted lenses. W.T. Ccolentz. Am. J. of Opthalmology 15, $932(1932)$. 